( Ю. С. СЕМЕНЮК, О. В. ПОТІЙКО, І. В. СИДОРУК, Ю. М. ОРДИНСЬКИЙ, В. А. ФЕДОРУК, В. Г. МІНІЧ, В. Б. ЛЕПЕХА, Н. М. АНДРУШКІВ

КЗ “Рівненська обласна клінічна лікарня" РОР

Центр лапароскопічних та малоінвазивних хірургічних втручань під контролем сонографії і ендоскопії імені Ю. Семенюка

\title{
Досвід лапароскопічних операцій у хворих на жовчнокам'яну хворобу
}

\author{
YU. S. SEMENIUK, O. V. POTIIKO, I. V. SYDORUK, YU. M. ORDYNSKYI, V. A. FEDORUK, V. H. MINICH, V. B. LEPEKHA, \\ N. M. ANDRUSHKIV
}

Municipal Institution "Rivne Regional Clinical Hospital" of Rivne Regional Council

Center for Laparoscopic and Minimally Invasive Surgical Procedures Controled by Sonography and Endoscopy by Yu. Semeniuk

\section{EXPERIENCE OF LAPAROSCOPIC SURGERIES IN PATIENTS WITH CHOLELITHIASIS}

У статті узагальнено досвід лікування хворих на жовчнокам'яну хворобу (ЖКХ) та відомості про ускладнення, які виникають під час здійснення лапароскопічних операцій. За 18 років (1997-2015) у Центрі виконано 10849 лапароскопічних холецистектомій (ЛХЕ). Проведений аналіз результатів операційного лікування 9047 (83,4 \%) пацієнтів із хронічним калькульозним холециститом (XKX) та 1802 (16,6 \%) пацієнтів із гострим калькульозним холециститом (ГКХ). Ретроспективно виконання ЛХЕ у Центрі ми поділили на три періоди: 1997-2002 рр. - освоєння методики ЛХЕ, 2003-2008 рр. - період розширення діапазону ЛХЕ (збільшення кількості хворих із деструктивними формами ГКХ), 2009-2015 рр. період вдосконалення ЛХЕ та впровадження власних технічних підходів у хворих із ЖКХ, розширення можливостей лапароскопії. Показник інтраопераційних ускладнень загалом за весь дослідний період становив 4,95 \%, за періодами цей показник був 9,4 \%; 5,1 \%; 1,2 \%. Загальна частота післяопераційних ускладнень склала 1,16 \%, за періодами $2,19 \% ; 1,08 \%$; 0,38 \%. Післяопераційна летальність становила 0,04 \% (4 хворих) та виникла у перші два періоди. У 242 (5,19\%) пацієнтів виконано симультанні операції. Серед проведених ЛХЕ повністю лапароскопічно симультанні операції було виконано в 70 (28,9 \%) пацієнтів. 130 (53,7 \%) хворих перенесли симультанні комбіновані лапароскопічні операції на органах черевної порожнини, 42 (17,4 \%) пацієнти перенесли симультанні поєднані операції, які покращили безпосередні та віддалені результати хірургічного лікування хворих. Середній термін лікування хворих після ЛХЕ за весь період спостереження склав $(3,27 \pm 0,81)$ дня, до операції - $(0,83 \pm 0,33)$ дня.

The article summarizes the experience of treating the patients with cholelithiasis and information on the complications that may arise during the laparoscopic surgery, the possibility of simultaneous operating. 18 years (1997-2015) there were 10 849 surgeries of laparoscopic cholecystectomies (LCE) conducted at the Center. There was also analysis of the results of surgical treatment of $9047(83.4 \%)$ patients with chronic calculous cholecystitis (CCC) and of 1802 (16.6 \%) patients with acute calculous cholecystitis (ACC). In retrospect, we divided the carrying out of LCE at the Center into three periods: period of 1997-2002 years - mastering of the LCE method, 2003-2008 years - period of the LCE diapason expansion (increase in the number of patients with destructive forms of ACC), 2009-2015 years - period of LCE development and implementation of own technical approaches to the patients with cholelithiasis, increasing the capabilities of the laparoscopy. In general for the whole research period the index of intra postoperative complications was $4.95 \%$, by periods this index was $9.4 \%$; $5.1 \%$; $1.2 \%$. The overall frequency of postoperative complications was $1.16 \%$, by periods $-2.19 \% ; 1.08 \% ; 0.38 \%$. Postoperative lethality was $0.04 \%$ (4 patients) and arose during the first two periods. 242 (5.19\%) patients underwent simultaneous surgeries. 70 (28.9\%) patients underwent fully simultaneous laparoscopic surgical interventions among the conducted LCE. 130 (53.7 \%) patients underwent simultaneous combined laparoscopic surgery on the abdominal cavity organs, $42(17.4 \%)$ patients underwent simultaneous compound surgenies that improved the immediate and late results of surgical treatment of patients. The average period of treatment of patients after the LCE for the entire follow-up period was $(3.27 \pm 0.81)$ days, before the surgical intervention - $(0,83 \pm 0,33)$ days.

Постановка проблеми і аналіз останніх досліджень та публікацій. 3 кожним роком все більше уваги приділяється раціональному використанню ліжкового фонду, щоб, в свою чергу, знизити рівень економічних затрат на діагностику та лікування пацієнтів.

Відповідно до світових стандартів лапароскопічна холецистектомія - “золотий стандарт” хірургічного лікування жовчнокам’яної хвороби [5,
9]. Серед дорослого населення частота виникнення жовчнокам'яної хвороби (ЖКХ) становить 10$15 \%$ [1, 8], в Україні за останні 10 років частота виявлення ЖКХ збільшилась у 2,1 раза [3].

Перевагами лапароскопічної холецистектомії (ЛХЕ) є мінімальна травматичність, косметичний ефект, зменшення реабілітаційного періоду та економічна ефективність. Порівняно $з$ традиційною холецистектомією: поліпшується візуалізація зони 
операційного втручання, особливо при глибокому розташуванні жовчного міхура у хворих з ожирінням і гіперстеніків, можливе виявлення супутніх захворювань органів черевної порожнини та виконання симультанних операцій без додаткового розрізу передньої черевної стінки.

Протипоказання до лапароскопічної холецистектомії суттєво змінювались в міру впровадження методу. Більшість протипоказань, сформульованих на початкових стадіях, перестали бути основними. Але в даному питанні слід зважати на досвід хірурга в лапароскопічній біліарній хірургії, технічне оснащення операційної та стан хворих, оскільки вони роблять проблематичним технічне виконання операції, впливають на ії безпеку і кінцевий результат.

Частота ускладнень, які виникають під час виконання лапароскопічної холецистектомії, становить від 2 до 12 \%, післяопераційна летальність 5-10 \% [2, 7], а серед хворих старших вікових груп летальність складає 15-26 \% [4].

3 огляду на поширення лапароскопічних технологій в хірургії, появу лапароскопічної апаратури не тільки в міських, а й у районних лікарнях, ми узагальнили досвід лікування хворих на ЖКХ та відомості про ускладнення, які виникають під час здійснення лапароскопічних операцій, можливість проведення симультанних операцій, деякі технічні підходи та прийоми, що сприятимуть більш активному впровадженню даних операцій та уникненню хірургами труднощів при їх виконанні.

Матеріали і методи. Ми здійснили ретроспективний аналіз історій хвороб 10889 хворих на ЖKX, які перебували на стаціонарному лікуванні в Центрі лапароскопічних та малоінвазивних хірургічних втручань під контролем сонографії і ендоскопії ім. Ю. Семенюка (далі Центр) в період від 1997 до березня 2015 р.

Пацієнтів із хронічним калькульозним холециститом (XKX) було 9047 (83,4 \%), гострий калькульозний холецистит (ГКХ) діагностовано у 1802 (16,6 \%) хворих, холестероз та поліпоз жовчного міхура мав місце у 102 пацієнтів.

Серед оперованих хворих у 316 (2,91 \%) діагностовано холедохолітіаз. У 299 (94,6 \%) пацієнтів холедохолітіаз та механічна жовтяниця ліквідовані шляхом проведення трансендоскопічної папілотомії $з$ наступним виконанням ЛХЕ. У 17 випадках трансендоскопічна холедохолітоекстракція проведена після ЛХЕ, причому в 12 хворих інтраопераційно був дренований холедох за Піковським.

Кількість хворих на ЖКХ, в яких на час перебування в Центрі було виявлено ще одну або кілька хірургічних хвороб, становила 271 (2,5 \%) чоловік. Із них прооперовано 242 пацієнтів, 29 хворих мали абсолютні протипоказання до виконання операційного втручання.

Кількість прооперованих хворих, в яких разом із ЖКХ було виявлено супутню хірургічну патологію органів черевної порожнини, становила 200 (82,6 \%) осіб, а кількість прооперованих хворих на ЖКХ та екстраабдомінальну хірургічну патологію - 42 (17,4 \%) пацієнти.

У 268 (2,47 \%) хворих в анамнезі були раніше перенесені операції на різних органах черевної порожнини (у 78 \% пацієнтів це були операції на нижньому поверсі, у 22 \% хворих післяопераційні рубці мали місце в епігастральній та умбілікальних ділянках).

Вік оперованих хворих перебував у межах від 17 до 84 років (найчастіше - 76 \% госпіталізували пацієнтів працездатного віку). Оперовано 82 \% жінок і $18 \%$ чоловіків.

Результати досліджень та їх обговорення. Ретроспективно виконання ЛХЕ у Центрі ми поділили на три періоди: період 1997-2002 рр. - освоєння методики ЛХЕ, 2003-2008 рр. - період розширення діапазону ЛХЕ (збільшення кількості хворих із деструктивними формами ГКХ), 2009-2015 рр. - період вдосконалення ЛХЕ та впровадження власних технічних підходів у хворих з ускладненими формами ЖKX, розширення можливостей лапароскопії (виконання симультанних операцій).

Кількість прооперованих хворих на ЖКХ, відповідно до періоду госпіталізації, наведено в таблиці 1.

За даними літератури, перехід до лапаротомії (конверсії) - негативний результат ЛХЕ, частота якої за відсутності суворої селекції пацієнтів становить 1,2-6,3 \% [2]. За результатами нашої роботи, в перші 6 років (період освоєння) частота конверсії становила - 0,96 \% (31 хворий), в наступний період вона склала 0,26 \% (10 хворих), в останньому періоді була одна (0,03 \%) конверсія.

Співвідношення хворих на ГКХ за періодами госпіталізації було 0,96:0,96:1,08. Причому в першому періоді переважали недеструктивні форми

Таблиця 1. Кількість лХЕ відповідно до періоду госпіталізації

\begin{tabular}{||c|c|c|c||}
\hline \hline \multirow{2}{*}{$\begin{array}{c}\text { Періоди } \\
\text { госпіталізації }\end{array}$} & \multicolumn{2}{|c||}{ ЛХЕ у хворих із: } & \multirow{2}{*}{ Всього } \\
\cline { 2 - 3 } & ХКХ & ГКХ & \\
\hline $1997-2002$ & 2623 & 576 & 3199 \\
\hline $2003-2008$ & 3218 & 577 & 3795 \\
\hline $2009-2015$ & 3206 & 649 & 3855 \\
\hline
\end{tabular}


ГКХ, що становило 73 \% пацієнтів (проводили селективний відбір пацієнтів до операції за сонографічними даними). У другому періоді співвідношення між недеструктивними та деструктивними формами ГКХ було 37 \% до 63 \% випадків. В третьому періоді переважали пацієнти із гострим деструктивним калькульозним холециститом (виявлено у 82 \% хворих) та ускладнені форми ЖКХ.

Структуру ускладнень після ЛХЕ в Центрі наведено в таблиці 2. Показник інтраопераційних ускладнень загалом за весь дослідний період становив 4,95 \%.

Якщо даний показник поділити, то в першому періоді (1997-2002 рр.) ускладнення під час операції ми спостерігали в 301 випадку, що становило 9,4 \%. У період 2003-2008 рр. кількість операцій зросла на 596 втручань, інтраопераційні ускладнення спостерігали в 195 (5,1%) випадках, тобто частота ускладнень зменшилась майже в 2 рази. У періоді 2009-2015 рр., після здобуття вагомого операційного досвіду, впровадження власного способу виконання ЛХЕ [6] та власних технічних прийомів під час операції, ретельного послідовного виконання етапів операції, володіння екстракорпоральними та інтракорпоральними методами лігування, видалення макропрепарату з черевної порожнини в контей- нері, екстракції жовчного міхура не в умбілікальній ділянці, нам вдалось зменшити кількість інтраопераційних ускладнень до 45 (1,2 \%) випадків.

В останній період (2009-2015 рр.) було виконано 70 (28,9 \%) повністю симультанних лапароскопічних операцій. 130 (53,7 \%) хворих перенесли симультанні комбіновані лапароскопічні операції на органах черевної порожнини (ЛХЕ + лапаротомія). 42 (17,4 \%) пацієнти перенесли симультанні поєднані операції (ЛХЕ + операція у хворого з екстраабдомінальною патологією). Структуру симультанних операцій, які виконано в Центрі, наведено в таблиці 3.

Схематично критерії оцінки ранніх післяопераційних результатів відображено в таблиці 4.

Загальна частота післяопераційних ускладнень склала 1,16 \% (126 хворих). Кількість післяопераційних ускладнень у третьому періоді, порівняно 3 попередніми роками, була найменшою - 0,38 \%. У період 1997-2002 рр. та 2003-2008 рр. післяопераційні ускладнення були, відповідно, 2,19 та 1,08 \%.

Післяопераційна летальність становила 0,04 \% (4 хворих) та виникла у перші два періоди. Два пацієнти померли від розлитого перитоніту (в одного була жовчотеча з міхурової протоки, в іншого пацієнта виникла перфоративна виразка ДПК), третій

Таблиця 2. Інтраопераційні ускладнення після лXE

\begin{tabular}{||l|c|c|c||}
\hline \multicolumn{1}{|c|}{ Вид ускладнень } & \multicolumn{3}{c||}{ Періоди, n (\%) } \\
\cline { 2 - 4 } & 1997-2002 pp. & 2003-2008 pp. & $2009-2015$ pp. \\
\hline Внутрішньочеревна кровотеча 3 ложа печінки & $71(2,2)$ & $46(1,2)$ & $18(0,47)$ \\
\hline Внутрішньочеревна кровотеча 3 міхурової артерії & $8(0,25)$ & $3(0,08)$ & 0 \\
\hline Пошкодження гепатикохоледоха & $2(0,06)$ & $1(0,03)$ & 0 \\
\hline Пошкодження внутрішніх органів & $5(0,16)$ & $2(0,05)$ & 0 \\
\hline $\begin{array}{l}\text { Ускладнення при евакуації макропрепарату з черевної } \\
\text { порожнини }\end{array}$ & $215(6,7)$ & $143(3,8)$ & $27(0,7)$ \\
\hline
\end{tabular}

Таблиця 3. Структура симультанних операцій

\begin{tabular}{||l|c||}
\hline \multicolumn{1}{|c|}{ Види операцій } & $\mathrm{n}(\%)$ \\
\hline ЛХЕ +Герніопластика & $141(58,3)$ \\
\hline ЛХЕ + Операції на внутрішніх жіночих статевих органах & $26(10,7)$ \\
\hline ЛХЕ + Видалення утворів органів черевної порожнини & $12(5,0)$ \\
\hline ЛХЕ + Видалення кісти печінки & $12(5,0)$ \\
\hline ЛХЕ + Адгезіолізис при злуковій хворобі очеревини & $6(2,5)$ \\
\hline ЛХЕ + Апендектомія & $2(0,8)$ \\
\hline ЛХЕ + Постановка перитонеального катетера & $1(0,4)$ \\
\hline ЛХЕ + Сафенектомія & $22(9,1)$ \\
\hline ЛХЕ + Нефректомія & $2(0,8)$ \\
\hline ЛХЕ + Тиреоїдектомія & $1(0,4)$ \\
\hline ЛХЕ + Операції з приводу захворювань шкіри та підшкірної клітковини & $17(7,0)$ \\
Всього & 242 \\
\hline \hline
\end{tabular}


Таблиця 4. Післяопераційні показники в оперованих хворих

\begin{tabular}{|c|c|c|c|}
\hline \multirow{2}{*}{ Критерій } & \multicolumn{3}{|c|}{ Періоди, n (\%) } \\
\hline & 1997-2002 pp. & $2003-2008$ pp. & 2009-2015 pp. \\
\hline \multicolumn{4}{|l|}{ Післяопераційні ускладнення: } \\
\hline жовчотеча з аберантної протоки & $7(0,23)$ & $5(0,13)$ & $2(0,05)$ \\
\hline жовчотеча 3 d. cysticus & $2(0,06)$ & $1(0,03)$ & 0 \\
\hline паренхіматозна кровотеча з ложа ж/м печінки & $3(0,09)$ & $2(0,05)$ & $1(0,03)$ \\
\hline перфоративна виразка ДПК & $1(0,03)$ & 0 & 0 \\
\hline інфільтрат рани & $42(1,31)$ & $24(0,63)$ & $10(0,26)$ \\
\hline нагноєння рани & $15(0,47)$ & $9(0,24)$ & $2(0,05)$ \\
\hline Летальні випадки & $2(0,06)$ & $2(0,05)$ & 0 \\
\hline 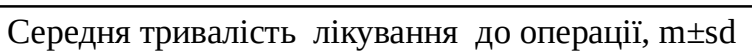 & $0,75 \pm 0,25$ & $1,14 \pm 0,19$ & $0,62 \pm 0,30$ \\
\hline 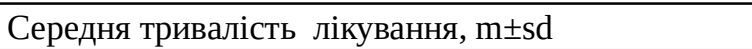 & $2,56 \pm 0,83$ & $3,49 \pm 0,28$ & $3,67 \pm 0,74$ \\
\hline
\end{tabular}

пацієнт помер від ТЕЛА, в останнього летальний випадок пов'язаний з прогресуванням ХНН.

Статистично не відрізнялась середня тривалість лікування хворих у трьох періодах. Слід відмітити, що за період 2009-2015 рр. було проведено найбільше ЛХЕ (3855 операцій), серед яких у 20 \% хворих мав місце ГКХ, також були проведені симультанні лапароскопічні операції у 200 (5,19\%) пацієнтів, але при цьому середній термін перебування в стаціонарі становив $(3,67 \pm 0,74)$ дня.

Середній термін лікування хворих після ЛХЕ за весь період спостереження склав $(3,27 \pm 0,81)$ дня, до операції - $(0,83 \pm 0,33)$ дня.

Висновки. 1. Для зниження частоти інтра- та післяопераційних ускладнень, отримання добрих результатів лікування хворих на ЖКХ за допомогою лапароскопічної техніки принципово важли-

\section{СПИСОК ЛІТЕРАТУРИ}

1. Андрющенко В. П. Поодинокі, численні, поєднані ускладнення гострого холециститу та можливість їх корекції з використанням загальноприйнятих і сучасних хірургічних технологій / В. П. Андрющенко, В. І. Прикупенко, Д. В. Андрющенко // Клін. хірургія. - 2004. - № 4-5. - С. 39.

2. Гончар М. Г. Інтраопераційні ускладнення під час виконання лапароскопічної холецистектомії / М. Г. Гончар, О. М. Глущук // Клін. хірургія. - 2012. - № 2. - С. 39-41.

3. Вибір тактики лікування при гострому калькульозному холециститі / В. М. Клименко, С. М. Кравченко, С. В. Вдовіло [та ін.] // Шпитальна хірургія. - 2004. - № 6. - С. 79-82.

4. Лікувальна тактика при калькульозному холециститі / Б. О. Мільков, В. В. Білоокий, М. М. Гресько, Д. Б. Домбровський // Шпитальна хірургія. - 2002. - № 3. - С. 14-26.

5. Ничитайло М. Е. Повреждения желчных протоков при холецистэктомии и их последствия / М. Е. Ничитайло, вим $є$ докладне вивчення анамнезу захворювання 3 метою виявлення жовтяниці в минулому; повне обстеження за допомогою УЗД та інших додаткових методів органів черевної порожнини, гепатопанкреатодуоденальної зони; висока кваліфікація хірургічної бригади, великий досвід фахівців у біліарної хірургї; ретельне послідовне виконання етапів операції.

2. Симультанні лапароскопічні операції покращують безпосередні та віддалені результати хірургічного лікування хворих, які мають декілька хірургічних захворювань.

3. При правильному індивідуальному відборі хворих, впровадженні та виконанні певних технічних прийомів під час операції ми досягли не тільки зменшення ризику інтра- та післяопераційних ускладнень, але й скоротили термін перебування пацієнта в стаціонарі до 3-4 діб.

А. В. Скумс. - К. : МАККОМ, 2006. - 343 с.

6. Семенюк Ю. С. Новий спосіб лапароскопічної холецистектомії при гострому холециститі / Ю. С. Семенюк, В. А. Федорук // Вісник Української медичної стоматологічної академiї. - 2008. - Т. 8, В. 1-2 (21-22). - С. 116-120.

7. Laparoscopic cholecystectomy: a safe approach for management of acute cholecystitis / S. Gourgiotis, N. Dimopoulos, S. Germanos [et al.] // JSLS. - 2007. - Vol. 11, № 21 - P. 219-224. 8. Laparoscopic-assisted combined colon and liver resection for primary colorectal cancer with synchronous liver metastases: initial experience / H. Kim, B. Lim, H. Ha [et al.] // World J. Surg. 2008. - Vol. 32 (12). - P. 2701-2706.

9. Laparoscopic hepatic left lateral lobectomy combined with fiber choledochoscopic exploration of the common bile duct and traditional open operation / K. Zhang, S. Zhang, Y. Jiang, P. Gao // World J. Gastroenterol. - 2008. - Vol. 14 (7). - P. 1133-1136. 